\title{
Isolation and Characterization of Hydrocarbon-Degrading Bacteria from Wastewaters in Ouagadougou, Burkina Faso
}

\author{
Adama Sawadogo1, Otoidobiga C. Harmonieㄹ, Joseph B. Sawadogoㄹ, Aminata Kaboré1, \\ Alfred S. Traoré1, Dayéri Dianou ${ }^{2 *}$ \\ ${ }^{1}$ Research Center for Biological, Alimentary and Nutritional Sciences, Research and Training Unit, Life and Earth \\ Sciences, University of Ouagadougou, Ouagadougou, Burkina Faso \\ ${ }^{2}$ National Center for Scientific and Technological Research, Institute for Health Sciences Research, \\ Ouagadougou, Burkina Faso \\ Email: dayerid@yahoo.fr
}

Received 2 April 2014; revised 1 May 2014; accepted 26 May 2014

Copyright (C) 2014 by authors and Scientific Research Publishing Inc.

This work is licensed under the Creative Commons Attribution International License (CC BY).

http://creativecommons.org/licenses/by/4.0/

(c) (i) Open Access

\begin{abstract}
Lubricants are very often found in nature under waste-oil forms and represent for the environment a real danger of pollution due to the difficulty of their biodegradation. The situation is especially worrying in most developing countries in particular those of Sub-Saharan Africa due to the absence of regulation or control. The present work aims to isolate bacterial strains able to degrade hydrocarbons which can later be used in biotechnology for environments depollution. Oil-contaminated wastewater samples were collected in Ouagadougou city (Burkina Faso) and then used as source of bacterial isolation. Appropriate amounts of samples were inoculated to a mineral salt medium (MS) with Total Quartz 9000 oil as sole carbon and energy source and then incubated for enrichment, prior to microbe isolation. Two bacterial strains namely $S_{2}$ and $S_{7}$ were isolated from the enrichment cultures. The strains were tested for their ability to degrade other hydrocarbons (i.e. gasoline, diesel oil, brake oil) and for temperature, $\mathrm{pH}$ and salt concentration ranges for growth before their biochemical characteristics were defined. Based on their morphological, physiological and biochemical traits, strains $S_{2}$ and $S_{7}$ belong to Acinetobacter and Pseudomonas genera, respectively.
\end{abstract}

\section{Keywords}

Biodegradation, Hydrocarbon, Bacteria, Wastewater, Depollution, Burkina Faso

\footnotetext{
${ }^{*}$ Corresponding author.
} 


\section{Introduction}

Lubricants are manufactured in various formulations for different applications. Most formulas generally consist of two fractions: chemicals additives and basic oils. Basic oils of lubricants are of mineral origin and derived from crude oil refining. They consist of three hydrocarbons families: paraffinic, naphthenic and aromatic [1]. Lubricants can also contain vegetable-base oils (triglycerides) in non-esterified forms as complex esters.

Release of hydrocarbons into the environment whether accidentally or due to human activities is a main cause of water and soil pollution [2] [3]. In many cases these lubricants are very often found in nature under used oil forms. Thus, in the European Union, 4.5 million tons of oil are consumed each year, along with 600,000 tons are lost in nature, leading to a real danger for environment pollution [4] [5]. The situation is especially worrying for most developing countries in general and those of Sub-Saharan Africa in particular because of the absence of policy for regulation and control. The presence of these products in the environment is a permanent threat, which can measure the extent of considering a liter of mineral oil polluting one million liters of water [6]. Soil contamination with hydrocarbons causes extensive damage of local system since accumulation of pollutants in animals and plant tissue may cause death or mutations [3] [7]. In the environment, non-volatile fractions of oils disperse in the aquatic environment or are absorbed into the ground creating a possible pollution of surface and ground waters [5]. These pollutions can affect a catchment area of drinking water. In addition, lubricants can cause a malfunction of biological sewage treatment plants and sewage sludge contamination. Finally, lubricants pose problems in agriculture by reducing the contaminated soil capacity of water retention [8]. Similarly, the spreading of polycyclic aromatic hydrocarbons (PAHs) on agricultural crops can result in a decrease of germination, stunting and yield reduction [9]. From the environment, hydrocarbons can also enter in food chains, leading to health problems. Thus, the soluble fractions of some of these compounds, in particular those containing mainly aromatic hydrocarbons and polar compounds are toxic (carcinogenic) for many species [10]. Similarly, oil particles inhaled in aerosol form can cause the occurrence of lipid pneumonia [11]. In the body, PAHs are mutagenic and can cause a decrease in the immune response with an increased risk of infections [12].

Fortunately, the degradation of these oils in the environment is possible through several techniques: physical [13], chemical [14] or biological [5] [15]-[19]. The technology commonly used for the soil remediation includes mechanical, burying, evaporation, dispersion, and washing. However, these technologies are expensive and can lead to incomplete decomposition of contaminants. The process of bioremediation, defined as the use of microorganisms to detoxify or remove pollutants owing to their diverse metabolic capabilities is an evolving method for the removal and degradation of many environmental pollutants including the products of petroleum industry [20]. In addition, bioremediation technology is believed to be noninvasive and relatively cost-effective [21]. Biodegradation by natural populations of microorganisms represents one of the primary mechanisms by which petroleum and other hydrocarbon pollutants can be removed from the environment [22] and is cheaper than other remediation technologies and the most efficient for environment safe depollution [23].

Among the microorganisms able to grow on hydrocarbons, bacteria remain qualitatively and quantitatively the most active agents [3] [24]-[29]. Based on the frequency of isolation, the predominant bacterial genera found on this issue are Pseudomonas, Acinetobacter, Alcaligenes, Vibrio, Flavobacterium, Achromobacter, Micrococcus, Nocardia and Corynebacteria [23] [28]-[30].

However, a number of limiting factors have been recognized to affect the biodegradation of petroleum hydrocarbons along with, temperature, salinity, oxygen content, oil concentration, presence of nutrients and hydrocarbon chemical composition [23] [31]-[39]. Many of these factors have been discussed by Brusseau [40]. The composition and inherent biodegradability of the petroleum hydrocarbon pollutant is the first and foremost important consideration when the suitability of a remediation approach is to be assessed. Among physical factors, temperature plays an important role in biodegradation of hydrocarbons by directly affecting the chemistry of the pollutants as well as affecting the physiology and diversity of the microbial flora [41]-[45]. Atlas [41] found that at low temperatures, the viscosity of the oil increased, while the volatility of the toxic low molecular weight hydrocarbons were reduced, delaying the onset of biodegradation. Temperature also affects the solubility of hydrocarbons [42]. Although hydrocarbon biodegradation can occur over a wide range of temperatures, the rate of biodegradation generally decreases with the decreasing temperature. Venosa and Zhu [43] reported that ambient temperature of the environment affected both the properties of spilled oil and the activity of the microorganisms. Significant biodegradation of hydrocarbons have been reported in psychrophilic environments in temperate regions [44] [45]. 
For the implementation of bioremediation technique, one important requirement is the presence of microorganisms with the appropriate metabolic capabilities. If these microorganisms are present, then optimal rates of growth and hydrocarbon biodegradation can be sustained by ensuring that adequate concentrations of nutrients and oxygen are present and that the $\mathrm{pH}$ is between 6 and 9 [23]. Unfortunately, at Sub-Saharan African countries level in general and Burkina Faso in particular, few studies focused on bioremediation technology for the depollution of hydrocarbon contaminated environments. To our knowledge, only one study relied on the biodegradation of hydrocarbons by a mixed inoculum containing bacteria, yeasts and fungi [8]. Unfortunately, the identity of microbes in the inoculum, and the conditions to optimize the process as well were not investigated. As also mentioned Das and Chandran [3], the scope of current understanding of oil bioremediation is also limited because the emphasis of most of these field studies and reviews has been given on the evaluation of bioremediation technology for dealing with large-scale oil spills on marine shorelines. However, an understanding of the impacts of oil on indigenous microbial communities and identification of oil-degrading microbial groups are prerequisite for directing the management and cleanup of oil-contaminated ecosystems [46].

Thus, in order to get insight of the bioremediation process of hydrocarbons in oil-contaminated environments of Ouagadougou city, the present study focused on the isolation, characterization and identification of indigenous hydrocarbon-degrading bacterial strains with regards to the conditions for optimizing their activities and the efficient cleanup of the hydrocarbon pollutants.

\section{Materials and Methods}

\subsection{Source of Isolation}

The source for bacterial isolation consisted of wastewaters contaminated with used motor oil, diesel and lubricating oils. Wastewater samples were collected into $500 \mathrm{ml}$ sterilized glass bottles from five sites in Ouagadougou (Table 1, Figure 1) on June 2011, immediately carried to the laboratory and stored at $+4^{\circ} \mathrm{C}$ in a refrigerator prior to use.

\subsection{Culture Media and Strains Isolation}

For strains isolation, enriched cultures were prepared according to Malatova [19], Mittal and Singh [5] and Kostka et al. [46]. Bushnell-Haas Broth was used in the enrichment technique. Tubes containing 9 ml of the nutrient broth supplemented with $3 \%(\mathrm{v} / \mathrm{v}) 0.22 \mu \mathrm{m}$ pore size filter-sterilized used motor oil as hydrocarbon substrate were inoculated in triplicate with $1 \mathrm{ml}$ of wastewater sample and then incubated on a horizontal shaker $(100 \mathrm{rpm})$ at $37^{\circ} \mathrm{C}$ for one month. After one week incubation period, $1 \mathrm{ml}$ of sample from primary enrichment was transferred to a fresh Bushnell-Haas Broth containing the same hydrocarbon and incubated as above. The bacterial growth was monitored by culture turbidity and depletion of added oil at regular intervals compared to controls with $0.22 \mu \mathrm{m}$ pore size filter-sterilized wastewater sample. After three subculturing steps in broth medium, 1 ml of enrichment culture was transferred into tubes containing $9 \mathrm{ml}$ of mineral salt (MS) medium supplemented with 3\% used motor oil as a single source of carbon and energy. The mineral salt (MS) medium, adapted from Mittal and Singh [5] and Olfa et al. [47] contained per liter: $\mathrm{KNO}_{3}, 1.0 \mathrm{~g}$; $\mathrm{MgSO}_{4} \cdot 7 \mathrm{H}_{2} \mathrm{O}, 1.0$ g; $\mathrm{CaCl}_{2} \cdot 6 \mathrm{H}_{2} \mathrm{O}, 0.1 \mathrm{~g}$; FeSO , 0.05 g; trace

Table 1. Location of the wastewater sampling sites in Ouagadougou, Burkina Faso.

\begin{tabular}{ccc}
\hline Sampling site & Zone & Geographic coordinates \\
\hline ABLASSE Garage & Tanghin & $12^{\circ} 23^{\prime} 31.8^{\prime \prime} \mathrm{LN}$ \\
$01^{\circ} 31^{\prime} 43.1^{\prime \prime} \mathrm{LW}$ \\
SONABEL Ouaga 1 & Paspanga & $12^{\circ} 23^{\prime} 02.7^{\prime \prime} \mathrm{LN}$ \\
& & $01^{\circ} 30^{\prime} 57.0^{\prime \prime} \mathrm{LW}$ \\
TAN-ALIZ Factory & Kossodo & $12^{\circ} 24^{\prime} 55.4^{\prime \prime} \mathrm{LN}$ \\
& & $01^{\circ} 28^{\prime} 33.4^{\prime \prime} \mathrm{LW}$ \\
KOSSODO Abattoir & Kossodo & $12^{\circ} 25^{\prime} 01.5^{\prime \prime} \mathrm{LN}$ \\
KARIM Garage & & $01^{\circ} 28^{\prime} 31.1^{\prime \prime} \mathrm{LW}$ \\
& Koulouba & $12^{\circ} 21^{\prime} 58.7^{\prime \prime} \mathrm{LN}$ \\
\hline
\end{tabular}

LN: Latitude North; LW: Longitude West. 


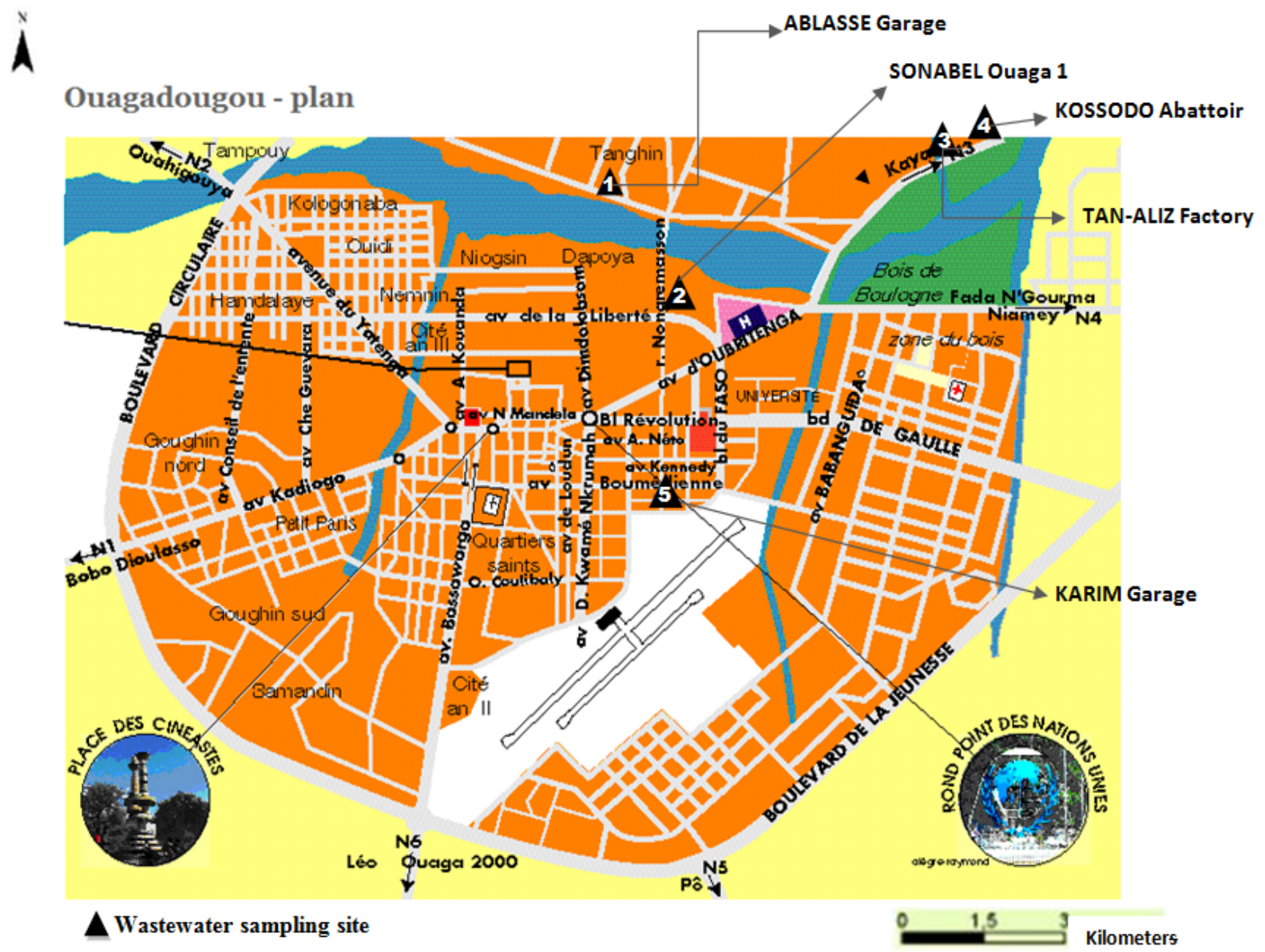

Figure 1. Location of wastewater sampling sites in Ouagadougou, Burkina Faso Sampling site: 1—ABLASSE Garage; 2SONABEL Ouaga 1; 3-TAN-ALIZ Factory; 4-KOSSODO Abattoir; 5-KARIM Garage.

elements of Pfennig et al. (1981), $250 \mathrm{ml}$; phosphate buffer (1 M, pH 6.8), $20 \mathrm{ml}$; and distilled water, $980 \mathrm{ml}$. Tubes were incubated at $37^{\circ} \mathrm{C}$ on a horizontal shaker $(100 \mathrm{rpm})$ for 7 days in the dark. Bacterial growth was monitored by measuring the optical density at $600 \mathrm{~nm}$ using a Milton Roy SPECTRONIC 601 spectrophotometer. After four successive transfers to fresh medium, $0.1 \mathrm{ml}$ of culture was plated after appropriate dilution on PCA agar and incubated at $37^{\circ} \mathrm{C}$ for one week as described by Mittal and Singh [5]. After 48 hours incubation period and later, single colonies appearing on the PCA agar were transferred on a fresh PCA agar and incubated. Pure colonies were obtained by using a single colony isolation procedure. The purity of cultures was confirmed by microscopic observations. Isolated colonies were stored at $4^{\circ} \mathrm{C}$ on PCA agar slants and subcultured at 3-week intervals or mixed with $40 \%$ glycerol and stored at $-70^{\circ} \mathrm{C}$ for future utilization.

\subsection{Growth Studies}

Experiments were conducted in the liquid MS medium described above with used motor oil (SAE40) as sole carbon and energy source. Growth was monitored by measuring optical density at $600 \mathrm{~nm}$ with a Milton Roy SPECTRONIC 601 spectrophotometer.

\subsection{Morphology}

The Gram stain reaction was determined with 4-day-old cultures by the modified method of Hucker described by Doetsch [48]. Cell morphology of 4-day-old colonies on PCA agar cultures and 4-day-old colonies cultures in the MS liquid medium as well were determined by oil immersion phase-contrast microscopy. Colony morphology and pigmentation were determined using 4-day-old PCA agar cultures. 


\subsection{Physiological Tests}

Growth at $\mathrm{pH}$ ranging from 4.5 to 9.0 was estimated in the MS liquid medium described above, where $\mathrm{pH}$ was adjusted with sterile $0.1 \mathrm{M} \mathrm{NaOH}$ or $\mathrm{HCl}$ solutions. The tested temperature range for growth was $30^{\circ} \mathrm{C}-44^{\circ} \mathrm{C}$. Tolerance to $\mathrm{NaCl}$ was monitored at concentrations ranging from $0.05 \%$ to $11.7 \%$ (w/v).

\subsection{Hydrocarbons Utilization}

The ability of strains to use the following hydrocarbons as sole carbon and energy source at a concentration of $3 \%(\mathrm{v} / \mathrm{v})$ was investigated after 7 days incubation period at $37^{\circ} \mathrm{C}$ : Diesel oil, Total Quartz 9000 motor oil, SAE40 used oil and gasoline. Controls without bacterial inoculation were prepared similarly. Experiments were performed in triplicate in $120 \mathrm{ml}$ flasks. The biodegradation capability was evaluated by monitoring bacterial growth through optical density measurement at $600 \mathrm{~nm}$ and by a gravimetric analysis according to Fusey and Oudot [49] as follow: $40 \mathrm{ml}$ of bacterial culture was added to $40 \mathrm{ml}$ of chloroform in a separating $200 \mathrm{ml}$ funnel which was then shaken vigorously to obtain two emulsified layers (a top layer consisting of a mixture of hydrocarbon and chloroform and a bottom layer containing water and biosurfactant in solution). The top layer was extracted and then passed through anhydrous sodium sulfate to remove moisture before the chloroform was evaporated on a water bath at $60^{\circ} \mathrm{C}$. The remaining residual hydrocarbon was estimated based on the weight of the empty funnel weight and the weight after chloroform evaporation and the \% of biodegradation was then evaluated in comparison to the initial hydrocarbon amount in the control funnel according to Fusey and Oudot [49].

\subsection{Biochemical Characteristics}

Biochemical tests were performed on 24-h-old cultures grown on Plate Count Agar (PCA) medium at $30^{\circ} \mathrm{C}$. Oxidase, catalase and respiratory mode were investigated according to Kovacs [50] and Smibert and Krieg [51]. Metabolism of citrate was studied by inoculating bacterial colonies on a Simmons' citrate agar medium. Enzymes for sugars (glucose, lactose) fermentation and $\mathrm{H}_{2} \mathrm{~S}$ production were studied using Kligler Hajna medium. Tests of orthonitrophenyl-beta-D-galactopyranosidase (ONPG), arginine dihydrolase (ADH), ornithine decarboxylase (ODC), lysine decarboxylase (LDC) were performed using the API 20E gallery according to the supplier's recommendations (Biomerieux, France).

\subsection{Kinetics of Strains Growth on Hydrocarbons}

Tests were performed in triplicate at optimal growth conditions ( $\mathrm{pH}$, temperature, $\mathrm{NaCl}$ and substrate concentrations) in tubes containing $9 \mathrm{ml}$ of the MS liquid medium supplemented with 3\% (v/v) of gasoline, Diesel oil, SAE40 used oil and Total Quartz 9000 motor oil, respectively. Tubes were then inoculated with 1 ml of bacterial suspension before they were incubated at the optimal growth temperature as defined through the physiological tests described above. Bacterial growth was monitored per $24 \mathrm{~h}$-incubation period up to 12 days by measuring the optical density at $600 \mathrm{~nm}$. The maximum growth rate ( $\mu$ max) of strains on the tested hydrocarbons was determined by the slope of the linear portion of the growth curve (exponential growth phase) as described by Smibert and Krieg [51].

\subsection{Statistical Analysis}

The data collected were subjected to analysis of variance (ANOVA) with regards to growth conditions and bacterial strain using XLSTAT-Pro 7.5 software. Mean variables were compared using the Newman Keuls test at probability level $\mathrm{p}=5 \%$.

\section{Results and Discussion}

\subsection{Enrichment and Isolation}

From the enrichment cultures, a total of six isolates able to use SAE40 used oil as carbon and energy source were obtained. Among the isolates, two strains namely $S_{2}$ and $S_{7}$ which showed the best growth (highest OD at $600 \mathrm{~nm}$ ) were selected for further characterization. 


\subsection{Morphology}

Colony morphology on agar medium revealed a translucent round form with $3-5 \mathrm{~mm}$ in size for strain $\mathrm{S}_{2}$ while strain $\mathrm{S}_{7}$ appeared yellowish, round and $2-3 \mathrm{~mm}$ in size. Both isolates stained Gram-negative and were nonmotile and motile for $S_{2}$ and $S_{7}$, respectively. Cells of strain $S_{2}$ were short rods, while slightly coccobacillus-like cells were also observed (Figure 2(a)), contrasting with the long rods bacillus-like cells of strain $\mathrm{S}_{7}$ (Figure 2(b)).

\subsection{Physiology}

\subsubsection{Temperature Range for Growth}

For both strains, growth was evident between $30^{\circ} \mathrm{C}$ and $39^{\circ} \mathrm{C}$ with an optimum at $36^{\circ} \mathrm{C}-37^{\circ} \mathrm{C}$ (Figure $3(\mathrm{a})$ ).

From the results obtained, the best temperature range for growth of both strains $S_{2}$ and $S_{7}$ is $35^{\circ} \mathrm{C}-38^{\circ} \mathrm{C}$ with an optimum at $37^{\circ} \mathrm{C}$ (Figure 3(a)). Under and above this temperature range, strains growth is rather low. As underlined Atlas and Bartha [52], Atlas [53] and Leahy and Colwell [23], temperature influences hydrocarbon biodegradation by its effect on the physical nature and chemical composition of the oil and the rate of hydrocarbon metabolism by microorganisms. According to Atlas and Bartha [52], at low temperatures, the viscosity of the oil increases, the volatilization of toxic short-chain alkanes is reduced, and their water solubility is increased, delaying the onset of biodegradation. Higher temperatures increase the rates of hydrocarbon metabolism to a maximum, typically in the range of $30^{\circ} \mathrm{C}$ to $40^{\circ} \mathrm{C}$, above which the membrane toxicity of hydrocarbons for microorganisms is increased leading to a decrease in metabolic activity [23] [37] [54]. The findings of these authors supported partially our results.

\subsection{2. pH Range}

The isolates grew at $\mathrm{pH}$ ranges of 7 - 8 for strain $\mathrm{S}_{7}$ and 7 - 9 for strain $\mathrm{S}_{2}$ with an optimum growth at $\mathrm{pH} 7.5$ and 8.5, respectively (Figure 3(b)). The pH ranges for growth of isolates $S_{2}$ and $S_{7}$ are in agreement with the results on hydrocarbon-degrading strains of Dibble and Bartha [39] and Hambrick et al. [38] who found that bacterial degradation of hydrocarbons is higher under slightly basic conditions and with those of Leahy and Colwell [23] who indicated that this activity is rather greater in neutral medium. However, in contrast to most aquatic ecosystems, soil $\mathrm{pH}$ can be highly variable, ranging from 2.5 in mine spoils to 11.0 in alkaline deserts [54]. According to Atlas [55], most heterotrophic bacteria and fungi favor a $\mathrm{pH}$ near neutrality, with fungi being more tolerant to acidic conditions and thus, extremes in $\mathrm{pH}$, as can be observed in some soils, would therefore be expected to have a negative influence on the ability of microbial populations to degrade hydrocarbons. Verstraete et al. [56] reported a near doubling of biodegradation rates for gasoline in an acidic (pH 4.5) soil by adjusting the $\mathrm{pH}$ to 7.4. They however noticed that biodegradation rates dropped significantly when the $\mathrm{pH}$ was further raised to 8.5. Similarly, Dibble and Bartha [39] observed an optimum pH of 7.8 for the mineralization of oily sludge in soil. As underlined Patrick et al. [57], the $\mathrm{pH}$ of sediments in special environments such as salt marshes may be as low as 5.0 in some cases. However, Hambrick et al. [38] found the rates of microbial mineralization of octade-

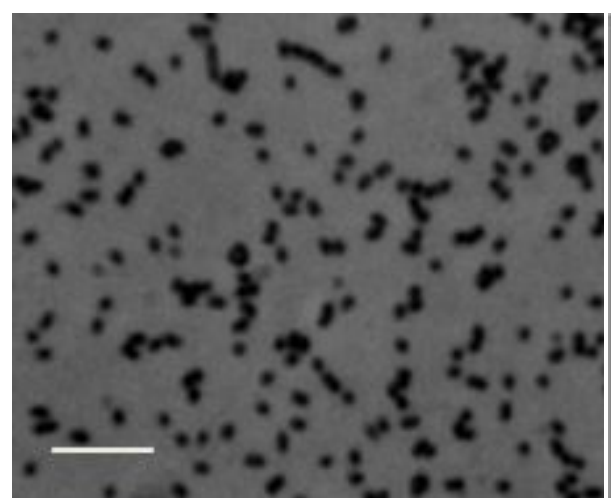

(a)

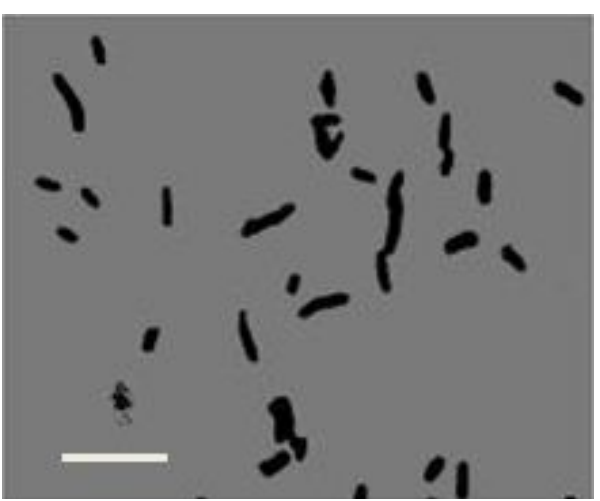

(b)

Figure 2. Cells' photomicrographs after Gram staining of hydrocarbon-degrading strains $\mathrm{S}_{2}$ (a) and $\mathrm{S}_{7}$ (b) isolated from wastewaters in Ouagadougou, Burkina Faso. The bar on (a) and (b) indicates $10 \mu \mathrm{m}$ (Photo: Sawadogo 2012). 


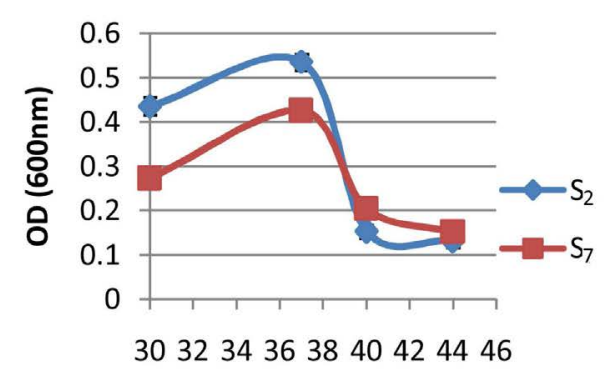

Temperature $\left({ }^{\circ} \mathrm{C}\right)$

(a)

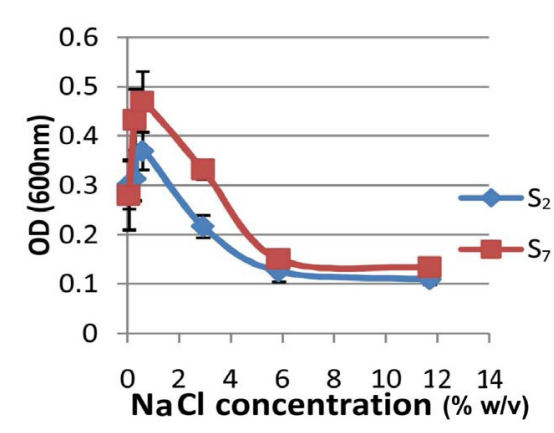

(c)

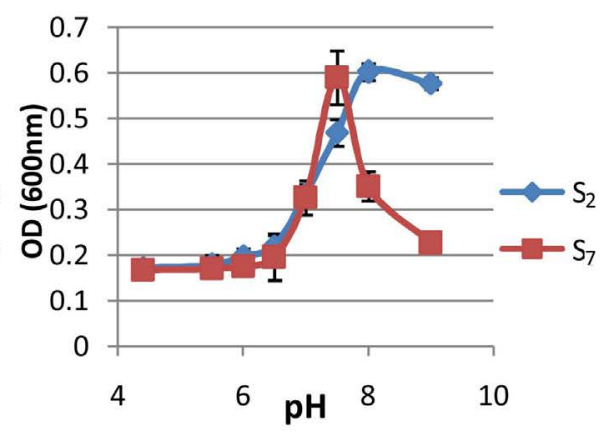

(b)

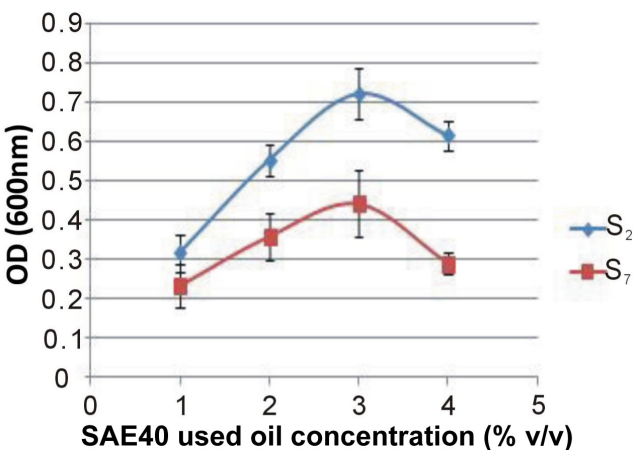

(d)

Figure 3. Temperature (a), $\mathrm{pH}$ (b), $\mathrm{NaCl}$ concentration (c) and SAE40 used oil concentration (d) ranges for growth of strains $\mathrm{S}_{2}$ and $\mathrm{S}_{7}$ (means of 3 replicates).

cane and napthalene to be depressed at this $\mathrm{pH}$ compared with $\mathrm{pH}$ 6.5. They also noticed that octadecane mineralization rates increased further when the $\mathrm{pH}$ was raised from 6.5 to 8.0 , whereas naphthalene mineralization rates did not. All the findings of these studies indicated clearly that the optimum $\mathrm{pH}$ for biodegradation may strongly be related to the nature and composition of the hydrocarbon in a given environment.

\subsubsection{Salinity}

Both isolates $\mathrm{S}_{2}$ and $\mathrm{S}_{7}$ support $\mathrm{NaCl}$ for growth at a concentration range of $0 \%-3 \%(\mathrm{w} / \mathrm{v})$ with an optimum growth at $0.6 \%-0.7 \%$ (Figure 3(c)). There are few published studies which deal with the effects of salinity on the microbial degradation of hydrocarbons. Shiaris [58] reported a positive correlation between salinity and mineralization rate of phenanthrene and naphthalene in estuarine sediments. Kerr and Capone [59] also observed a relationship between the naphthalene mineralization rate and salinity in sediments of the Hudson river that was dependent upon the ambient salinity regime, with estuarine sites exhibiting a lack of mineralization inhibition over a wider range of salinities than was the case for the less saline upstream site. In a study of hypersaline salt evaporation ponds, Ward and Brock [60] showed that rates of hydrocarbon metabolism decreased with increasing salinity in the range $3.3 \%$ to $28.4 \%$ and attributed the results to a general reduction in microbial metabolic rates. Our result is supported by Csonka and Epstein [61] who reported that high concentration of salt in the growth medium may decrease the water activity of the surrounding environment, which decrease can disrupt the normal cellular activities and the growth of bacteria. However, our finding contrasts with the data of Bertrand et al. [35] who found an optimum $\mathrm{NaCl}$ concentration of $2.34 \%(0.4 \mathrm{M})$ for two hydrocarbon-degrading microbial communities and with those of Ward and Brock [60]. One reason of the difference with their data could be explained by the fact that these authors focused on marine bacteria, known to support high salt concentration and hypersaline environments as well.

\subsubsection{Hydrocarbon Concentration}

For all the hydrocarbons tested, $3 \%(\mathrm{v} / \mathrm{v})$ although rather low appeared the best substrate concentration providing the optimum growth for both strains $S_{2}$ and $S_{7}$ (Figure 3(d)). The rates of uptake and mineralization of many 
organic compounds by microbial populations in the aquatic environment are proportional to the concentration of the compound, generally conforming to Michaelis-Menten kinetics [23] [62] [63]. However, according to Button and Robertson [64] and Robertson and Button [65], Michaelian kinetics have been demonstrated for the microbial uptake and oxidation of low molecular-weight aromatic hydrocarbons of relatively high water solubility, but may not apply to the more insoluble hydrocarbons. In line with that, Wodzinski and Bertolini [66], Wodzinski and Coyle [67] and Thomas et al. [68] showed that the rates of mineralization of high molecular-weight aromatic hydrocarbons, such as naphthalene and phenanthrene, are related to aqueous solubility rather than total substrate concentrations. The microbial degradation of long (C12) alkanes, for which solubility is less than 0.01 $\mathrm{mg} / \mathrm{liter}$, occurs at rates which exceed the rates of hydrocarbon dissolution [68]-[70] and is a function of the hydrocarbon surface area available for emulsification or physical attachment by cells [71]-[73]. Therefore, biodegradation rates for many hydrocarbons will not display the dependence on concentration which is typically observed with more soluble organic substrates. High concentrations of hydrocarbons can be associated with heavy undispersed oil slicks in water, causing inhibition of biodegradation by nutrient or oxygen limitation or through toxic effects exerted by volatile hydrocarbons [23]. Fusey and Oudot [49] reported that contamination of seashore sediments with crude oil above a threshold concentration prevented biodegradation of the oil because of oxygen and/or nutrient limitation. As also mentioned Soltani [54], a high hydrocarbon concentration leads to the formation of large masses having a low contact surface area with the culture medium and thus, results in microbial growth inhibition. The concept of a maximum or threshold concentration for microbial degradation of hydrocarbons may apply also to soil ecosystems. Dibble and Bartha [39] reported increases in $\mathrm{CO}_{2}$ evolution over the range of $1.25 \%$ to $5 \%$ hydrocarbon mass per dry weight of soil, when oil sludge was applied to soil. No increase was observed at a level of $10 \%$ and the rates declined at $15 \%$. They concluded that decreases in activity at high oil loading concentrations were ascribed to inhibition of microbial activity by toxic components of the oil sludge [39]. All these findings suggest that the concept of a maximum or threshold concentration for microbial degradation of hydrocarbons may be related to the pollutant type and environmental factors.

\subsubsection{Hydrocarbon Utilization}

The growth variance in MS medium with hydrocarbon as sole carbon and energy source at $37^{\circ} \mathrm{C}, \mathrm{pH} 8.5$ and 7.5 for strains $S_{2}$ and $S_{7}$, respectively is presented in Table 2. After 12 days incubation period, strains $S_{2}$ and $S_{7}$ showed a significant difference for the hydrocarbons tested $(p=0.05$, Table 2). However, no significant difference was found among hydrocarbons for strain $S_{2}$ and strain $S_{7}$ as well $(p=0.461)$. The combined effects of hydrocarbon source and strain showed also no significant difference $(p=0.235)$. The maximum growth rates $(\mu \max )$ of strains $S_{2}$ and $S_{7}$ were determined on different hydrocarbons: SAE 40 used oil, Total Quartz 9000, Diesel oil and gasoline. From the results obtained (Figure 4), strain $\mathrm{S}_{2}$ showed the highest growth rates on SAE 40 used oil, Total Quartz 9000, Diesel oil and gasoline (0.169 $\pm 0.067,0.140 \pm 0.051,0.128 \pm 0.011$ and $0.109 \pm 0.026$, respectively) compared to the ones of strain $\mathrm{S}_{7}(0.130 \pm 0.045,0.101 \pm 0.015,0.096 \pm 0.015$ and $0.093 \pm 0.015$, respectively). For all the hydrocarbons tested, statistical analysis showed no significant difference between the growth rates of strains $S_{2}$ and $S_{7}(p>0.05$, Figure 4). However, a significant difference between both strains was observed for each hydrocarbon tested $(p=0.05$, Figure 4$)$.

Although no significant difference in growth of both strains was observed between the hydrocarbons tested (Table 2, Figure 4), the growth on SAE 40 used oil appeared relatively the highest and the one on gasoline the lowest compared to the growth on the other hydrocarbons (Figure 4). According to Ratledge [74], the short aliphatic hydrocarbon chains abundant in gasoline can dissolve in the culture medium and become toxic to bacteria, thus justifying the low growth observed with gasoline. Wrenn and Venosa [75] also underlined that many polyaromatic hydrocarbon rings present in used oil can lead to the formation of colored compounds during their degradation. These colored compounds can increase the turbidity of the culture medium and thus leading to an overestimation of the OD and $\mu$ max. However, since no significant difference was observed between the hydrocarbons tested, this point may influence very weakly or not the results obtained in the present study.

The gravimetric analysis according to Fusey and Oudot [49] for Diesel oil, SAE 40 used oil and Total Quartz 9000 motor oil revealed after 7 days incubation period, biodegradation rates of 50.62\% $\pm 1.55 \%, 20.41 \% \pm 3.88 \%$ and $16.26 \% \pm 0.38 \%$, respectively with strain $\mathrm{S}_{2}$, while $10.33 \% \pm 2.33 \%, 6.28 \% \pm 1.61 \%$, and $3.31 \% \pm 1.56 \%$, respectively with strain $S_{7}$. The discrepancy of these data with those of the growth studies (Figure 4) can be related to the gravimetric estimation used. As underlined Bossert and Bartha [37], the presence of particulate matter, affects the physical and chemical nature of the oil and hence its susceptibility to microbial degradation. In 
Table 2. Variance of hydrocarbons utilization with regards to bacterial strain and hydrocarbon type (means of 3 replicates).

\begin{tabular}{cccc}
\hline Source of variation & df & $\mathrm{p}$ & $\mathrm{F}$ \\
\hline Strain & 1 & 0.05 & $\mathrm{~s}$ \\
Hydrocarbon & 3 & 0.461 & $\mathrm{~ns}$ \\
Strain $\times$ Hydrocarbon & 7 & 0.235 & $\mathrm{~ns}$ \\
\hline
\end{tabular}

ns: not significant; s: significant; df: degree of freedom; $\mathbf{p}=$ probability at a risk of 5\%; F: Fischer’ test.

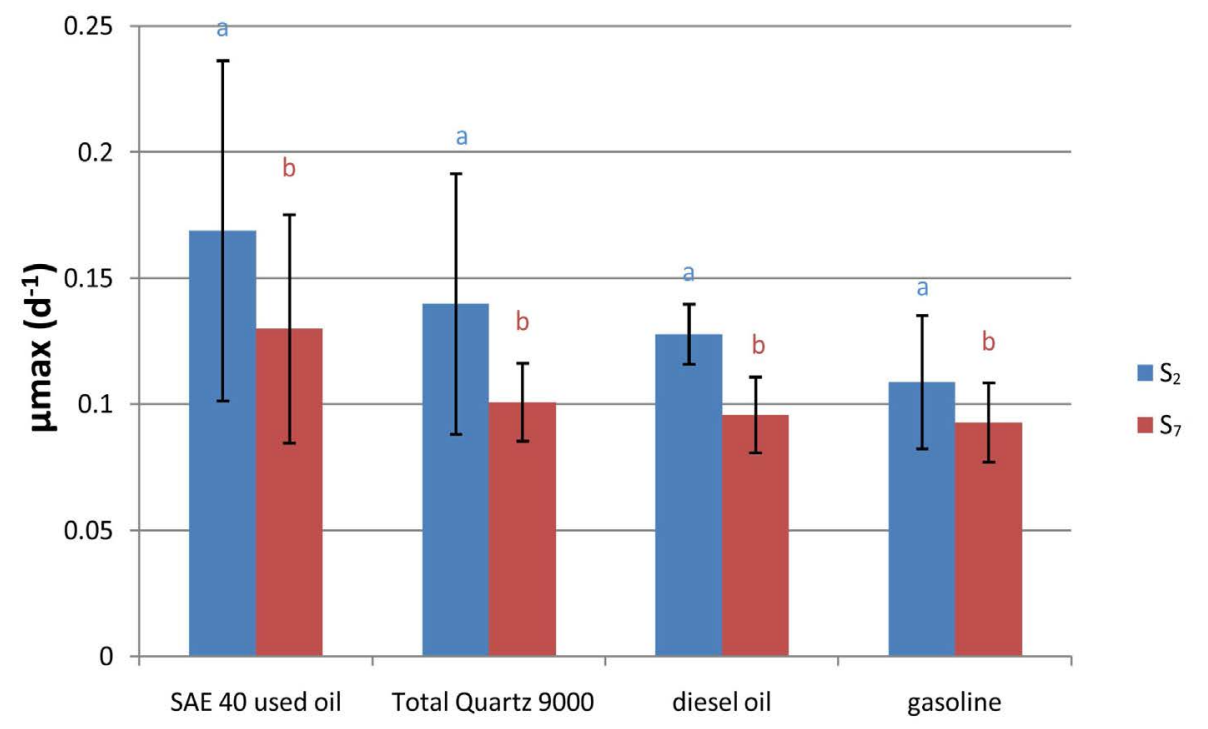

Hydrocarbon

Figure 4. Maximum growth rate ( $\mu \mathrm{max}$ ) of strains $\mathrm{S}_{2}$ and $\mathrm{S}_{7}$ at optimum growth conditions $\left(37^{\circ} \mathrm{C}, \mathrm{pH} 7.5\right.$ and $8.5,0.5 \%-0.6 \%(\mathrm{w} / \mathrm{v})$ and $3 \%(\mathrm{v} / \mathrm{v}) \mathrm{NaCl}$ and hydrocarbon concentrations, respectively) on SAE 40 used oil, Total Quartz 9000, diesel oil and gasoline. For both strains and for all the hydrocarbons experienced, values sharing the same letter are not significantly different according to the Newman-Keuls test at $\mathrm{p}=5 \%$.

the present study, the probable presence of particulate matter in Diesel oil and SAE 40 used oil may lead to an overestimation of the biodegradation rates with these oils compared to Total Quartz 9000 motor oil one when using the gravimetric method.

\subsection{Biochemical Characteristics}

The tests carried out revealed that cells of strain $\mathrm{S}_{2}$ were oxidase-negative, ONPG-negative, ADH-negative, ODCnegative, LDC-negative, $\mathrm{H}_{2} \mathrm{~S}$-negative and indole-negative, while Cells of strain $\mathrm{S}_{7}$ appeared catalase-positive, oxidase-positive, ONPG-negative, ADH-positive, ODC-negative, LDC-negative, $\mathrm{H}_{2} \mathrm{~S}$-negative and indole-negative (Table 3). Both strains are strict aerobes and able to ferment citrate and glucose but not lactose.

\subsection{Taxonomy}

The morphological, physiological and biochemical characteristics (Table 3) indicate that strains $\mathrm{S}_{7}$ and $\mathrm{S}_{2}$ are very closely related to Pseudomonas and Acinetobacter genera, respectively. According to some authors [3] [5] [13] [15] [17]-[19] [23] [30], bacterial strains belonging to these two genera are generally able to degrade hydrocarbons. Our isolates can grow in MS medium supplemented with hydrocarbons as sole carbon and energy source and thus, sustaining their capability to degrade hydrocarbons in agreement with the finding of these authors. However, the determination of the genetic characteristics of our isolates remains of utmost importance to confirm their affiliation to these genera and for their full characterization and identification at species level. 
Table 3. Phenotypic characteristics of strains $\mathrm{S}_{2}$ and $\mathrm{S}_{7}$ and related genera.

\begin{tabular}{|c|c|c|c|c|}
\hline Characteristic & $\mathrm{S}_{2}$ & $\mathrm{~S}_{7}$ & Pseudomonas $^{1}$ & Acinetobacter $^{2}$ \\
\hline \multicolumn{5}{|l|}{ Colony morphology } \\
\hline Form & Round & Round & Round & Round \\
\hline Size (mm) & $3-5$ & $2-3$ & Small & $0.5-2$ \\
\hline Color & Translucent & Yellowish & Yellow & Translucent, opaque \\
\hline Cell morphology & $\begin{array}{c}\text { Short rod } \\
\text { Coccobacillus-like }\end{array}$ & $\begin{array}{l}\text { Long rod } \\
\text { Bacillus-like }\end{array}$ & $\begin{array}{l}\text { Long rod } \\
\text { Bacillus-like }\end{array}$ & $\begin{array}{c}\text { Short rod } \\
\text { Coccobacillus-like }\end{array}$ \\
\hline Motility & - & + & + & $+/-$ \\
\hline $\begin{array}{c}\text { Physiology } \\
\text { Hydrocarbons utilization }\end{array}$ & + & + & + & + \\
\hline \multicolumn{5}{|l|}{ Substrates fermented } \\
\hline Glucose & + & + & + & $+/-$ \\
\hline Lactose & - & - & - & $+/-$ \\
\hline Citrate & + & + & + & $+/-$ \\
\hline Respiratory metabolism & Strictly aerobic & Strictly aerobic & Strictly aerobic & Strictly aerobic \\
\hline Optimal growth temperature & $37^{\circ} \mathrm{C}$ & $37^{\circ} \mathrm{C}$ & $30^{\circ} \mathrm{C}-35^{\circ} \mathrm{C}$ & $30^{\circ} \mathrm{C}-37^{\circ} \mathrm{C}$ \\
\hline \multicolumn{5}{|l|}{ Biochemical characteristics } \\
\hline Gram stain & - & - & - & - \\
\hline Oxidase & - & + & + & - \\
\hline Catalase & + & + & + & + \\
\hline ONPG & - & - & - & - \\
\hline $\mathrm{ADH}$ & - & + & + & - \\
\hline LDC & - & - & - & - \\
\hline ODC & - & - & - & - \\
\hline $\mathrm{H}_{2} \mathrm{~S}$ & - & - & - & - \\
\hline Indole & - & - & - & - \\
\hline
\end{tabular}

+: positive, -: negative, ${ }^{1}$ Franzetti and Scarpellini [76]; ${ }^{2}$ Constantiniu et al. [77].

\section{Conclusion}

The ability of various indigenous bacteria (especially those isolated from contaminated sites) to metabolize crude oil or aliphatic hydrocarbons is well known. In this study, bacterial strains that are able to grow on used oil as a carbon and energy source were isolated from hydrocarbon-contaminated wastewaters in Ouagadougou, Burkina Faso. The enrichment technique was used for selecting hydrocarbon degraders. Growth on various hydrocarbons revealed the presence of hydrocarbon- and oil-degrading activities in the isolated bacterial strains. Based on the morphological, biochemical and physiological characteristics defined, the isolated hydrocarbondegrading strains $\mathrm{S}_{7}$ and $\mathrm{S}_{2}$ appear to be related to Pseudomonas and Acinetobacter genera, respectively. However, to confirm their affiliation to these genera, and for a full characterization and identification, the determination of genetic characteristics (16S rDNA and key enzymes encoding genes sequences analysis) and refining their physiology for their ability to use high/low molecular hydrocarbons are required. The optimization of the bioremediation ability of the strains may also require a full elucidation of the metabolic pathways and the key enzymes involves in both strains during hydrocarbons degradation. In order to increase the feasibility of the bacterial isolates as potential commercial strains, future studies need to clarify the factors affecting the ability and efficiency of hydrocarbon and crude oil degradation, such as nutrient concentration, oxygen content and physical state of the oil.

\section{Acknowledgements}

The authors would like to express profound gratitude to ISP-SUEDE, PACER-UEMOA, CRSBAN-RABIO- 
TECH, UFR-SVT/UO and CNRST/IRSS, for financial and technical supports.

\section{References}

[1] Frédérique, H., Guy-Alain, J., Etienne, P., Jean, G., Olivier, B. and Guillaume, C. (1999) Study of the Biodegradability of Basic Oils Used in the Manufacture of Lubricants. Oleaginous, Fatty Substance, Lipids: Lipochemistry and Sustainable Development, 6, 389-392.

[2] Holliger, C., Gaspard, S., Glod, G., et al. (1997) Contaminated Environments in the Subsurface and Bioremediation: Organic Contaminants. FEMS Microbiology Reviews, 20, 517-523. http://dx.doi.org/10.1111/j.1574-6976.1997.tb00334.x

[3] Das N. and Chandran P. (2011) Microbial Degradation of Petroleum Hydrocarbon Contaminants: An Overview. Biotechnology Research International, 2011, Article ID: 941810. http://dx.doi.org/10.4061/2011/941810

[4] Van Donkelaar, P. (1990) Environmental Effects of Crankcase and Mixed Lubrication. Science of the Total Environment, 92, 165-179. http://dx.doi.org/10.1016/0048-9697(90)90328-R

[5] Mittal, A. and Singh, P. (2009) Isolation of Hydrocarbon-Degrading Bacteria from Soils Contaminated with Crude Oil Spills. Indian Journal of Experimental Biology, 47, 760-765.

[6] De Caro, P. and Cecutty, O. (2005) Lubricants and Environment. Oleaginous, Fatty Substance, Lipids, 12, $279-283$.

[7] Alvarez, P.J.J. and Vogel, T.M. (1991) Substrate Interactions of Benzene, Toluene, and Para-Xylene during Microbial Degradation by Pure Cultures and Mixed Culture Aquifer Slurries. Applied and Environmental Microbiology, 57, 2981-2985.

[8] Ouédraogo, P.W.K., Savadogo, P.W., Ouattara, C.A.T., Savadogo, A. and Traoré, A.S. (2010) Study of Hydrocarbon-Contaminated Soils Biodepollution in Burkina Faso. Journal of the West African Society of Chemistry, 30, 19-28.

[9] Chaineau, C.H., Morel, J.L. and Oudot, J. (1996) Land Treatment of Oil-Based Drill Cuttings in an Agricultural Soil. Journal of Environmental Quality, 25, 858-867. http://dx.doi.org/10.2134/jeq1996.00472425002500040030x

[10] National Institute for Research and Security (INRS) (2006) Fossil and Petroleum Fuels. ed. 989. Technical HelpMemory, Paris.

[11] Breton, J.L., Ranfaing, E., Clément, F. and Faure, E. (1990) Exogenous Lipid Pneumopathy of Professional Origin. The Medical Press, 1724.

[12] Gasperi, J. (2006) Introduction and Transfer of Hydrocarbons at Different Spatial Scales in the Parisian Network of Sanitation. Doctorate Thesis, University of Paris XII, Créteil, 272 p.

[13] Costes, J.M. and Druelle, V. (1997) Polyciclic Aromatic Hydrocarbons in the Environment: The Rehabilitation of Old Industrial Sites. Oil and Gas Science and Technology, 52, 425-440. http://dx.doi.org/10.2516/ogst:1997051

[14] Chu, W. and Kwan, C.Y. (2003) Remediation of Contaminated Soil by a Solvent/Surfactant System. Chemosphere, 53, 9-15. http://dx.doi.org/10.1016/S0045-6535(03)00389-8

[15] Hamme, J.D., Singh, A. and Ward, O.P. (2003) Recent Advances in Petroleum Microbiology. Microbiology and Molecular Biology Reviews, 67, 503-549. http://dx.doi.org/10.1128/MMBR.67.4.503-549.2003

[16] Koma, D., Hasumi, S. and Motoki, K. (2003) Biodegradation of N-Alkylcyclohexane by Co-Oxidation via Multiples Pathways Acinetobacter sp. Oddk71. Journal of Bioscience and Bioengineering, 95, 641-644. http://dx.doi.org/10.1016/S1389-1723(03)80178-0

[17] Parales, P.E. and Haddock, J.D. (2004) Biocatalytic Degradation of Pollutants. Current Opinion in Biotechnology, 15, 374-379. http://dx.doi.org/10.1016/j.copbio.2004.06.003

[18] Pieper, D.H., Dos Santos, V.M. and Golyshin, P.N. (2004) Genomic and Mechanistic Insight into the Biodegradation of Organic Pollutant. Current Opinion in Biotechnology, 15, 215-224. http://dx.doi.org/10.1016/j.copbio.2004.03.008

[19] Malatova, K. (2005) Isolation and Characterization of Hydrocarbon Degrading Bacteria from Environmental Habitats in Western New York State. Master of Science in Chemistry Thesis, Department of Chemistry, Rochester Institute of Technology, Rochester, 108 p.

[20] Medina-Bellver, J.I., Marın, P., Delgado, A., Rodríguez-Sánchez, A., Reyes, E., Ramos, J.L. and Marqués, S. (2005) Evidence for in Situ Crude Oil Biodegradation after the Prestige Oil Spill. Environmental Microbiology, 7, 773-779. http://dx.doi.org/10.1111/j.1462-2920.2005.00742.x

[21] April, T.M., Foght, J.M. and Currah, R.S. (2000) Hydrocarbon-Degrading Filamentous Fungi Isolated from Flare Pit Soils in Northern and Western Canada. Canadian Journal of Microbiology, 46, 38-49. http://dx.doi.org/10.1139/cjm-46-1-38

[22] Ulrici, W. (2000) Contaminant Soil Areas, Different Countries and Contaminant Monitoring of Contaminants. In: Rehm, H.J. and Reed, G., Eds., Environmental Process II. Soil Decontamination Biotechnology, Vol. 11, 5-42. 
[23] Leahy, J.G. and Colwell, R.R. (1990) Microbial Degradation of Hydrocarbons in the Environment. Microbiological Reviews, 54, 305-315.

[24] Bertrand, J.C. and Mille, G. (1989) Future of Exegenous Organic Matter. A Model: Hydrocarbons. In: Bianchi, M., Marty, D., Bertrand, J.C., Caumette, P. and Gauthier, M.J., Eds., Microorganisms in the Oceanic Ecosystems, Masson, Paris, 343-385.

[25] MacNaughton, S.J., Stephen, J.R., Venosa, A.D., Davis, G.A., Chang, Y.J. and White, D.C. (1999) Microbial Population Changes during Bioremediation of An Experimental Oil Spill. Applied and Environmental Microbiology, 65, 3566-3574.

[26] Rahman, K.S.M., Rahman, T.J., Kourkoutas, Y., Petsas, I., Marchant, R. and Banat, I.M. (2003) Enhanced Bioremediation of $N$-Alkane in Petroleum Sludge Using Bacterial Consortium Amended with Rhamnolipid and Micronutrients. Bioresource Technology, 90, 159-168. http://dx.doi.org/10.1016/S0960-8524(03)00114-7

[27] Yakimov, M.M., Timmis, K.N. and Golyshin, P.N. (2007) Obligate Oil Degrading Marine Bacteria. Current Opinion in Biotechnology, 18, 257-266. http://dx.doi.org/10.1016/j.copbio.2007.04.006

[28] Adebusoye, S.A., Ilori, M.O., Amund, O.O., Teniola, O.D. and Olatope, S.O. (2007) Microbial Degradation of Petroleum Hydrocarbons in a Polluted Tropical Stream. World Journal of Microbiology and Biotechnology, 23, 1149-1159. http://dx.doi.org/10.1007/s11274-007-9345-3

[29] Brooijmans, R.J.W., Pastink, M.I. and Siezen, R.J. (2009) Hydrocarbon-Degrading Bacteria: The Oil-Spill Clean-Up Crew. Microbial Biotechnology, 2, 587-594. http://dx.doi.org/10.1111/j.1751-7915.2009.00151.x

[30] Floodgate, G.D. (1995) Some Environmental Aspects of Marine Hydrocarbon Bacteriology. Aquatic Microbial Ecology, 9, 3-11. http://dx.doi.org/10.3354/ame009003

[31] Walworth, J., Braddock, J. and Woolard, C. (2001) Nutrient and Temperature Interactions in Bioremediation of Cryic Soil. Cold Regions Science and Technology, 32, 85-91. http://dx.doi.org/10.1016/S0165-232X(00)00020-3

[32] Mohn, G.D. and Stewart, G.R. (2000) Limiting Factors for Hydrocarbons at Low Temperature in Arctic Soils. Soil Biology and Biochemistry, 32, 1161-1172. http://dx.doi.org/10.1016/S0038-0717(00)00032-8

[33] Marin, M., Pedregosa, A., Rios, S. and Laborda, F. (1996) Study of Factors Influencing the Degradation of Heating Oil by Acinetobacter calcoaceticus MM5. International Biodeterioration and Biodegradation, 38, 69-75. http://dx.doi.org/10.1016/S0964-8305(96)00027-3

[34] Cloesen, C. (2006) Study of Lubricant Properties of Vegetal Biodegradable Oils. Third Activities Report, Wallon Region Convention, University of Liège, EMT, Liège.

[35] Bertrand, J.C., Bianchi, M., Al Mallah, M., Acquaviva, M. and Mille, G. (1993) Hydrocarbon Biodegradation and Hydrocarbonoclastic Bacterial Communities Composition Grown in Seawater as a Function of Sodium Chloride Concentration. Journal of Experimental Marine Biology and Ecology, 168, 125-138. http://dx.doi.org/10.1016/0022-0981(93)90119-9

[36] Al-Mallah, M. (1988) Biodégradation of Hydrocarbons in Hypersalty Environments. Doctorate Thesis, University of Aix Marseille II, Provence, 192 p.

[37] Bossert, I. and Bartha, R. (1984) The Fat of Petroleum in Soil Ecosystems. In: Atlas, R.M., Ed., Petroleum Microbiology, Macmillan, New York, 440-445.

[38] Hambrick, G.A., Delaune, R.D. and Patrick Jr., W.H. (1980) Effect of Estuarine Sediment pH and Oxidation-Reduction Potential on Microbial Hydrocarbon Degradation. Applied and Environmental Microbiology, 40, 365-369.

[39] Dibble, J.T. and Bartha, R. (1979) Effect of Environmental Parameters on the Biodegradation of Oil Sludge. Applied and Environmental Microbiology, 37, 729-739.

[40] Brusseau, M.L. (1998) The Impact of Physical, Chemical and Biological Factors on Biodegradation. In: Serra, R., Ed., Proceedings of the International Conference on Biotechnology for Soil Remediation: Scientific Bases and Practical Applications, C.I.P.A. S.R.L., Milan, 81-98.

[41] Atlas, R.M. (1975) Effect of the Temperature and Crude Oil Composition on Petroleum Biodegradation. Applied Microbiology, 30, 396-403.

[42] Foght, J.M., Westlake, D.W.S., Johnson, W.M. and Ridgway, H.F. (1996) Environmental Gasoline-Utilizing Isolates and Clinical Isolates of Pseudomonas aeruginosa Are Taxonomically Indistinguishable by Chemotaxonomic and Molecular Techniques. Microbiology, 142, 2333-2340. http://dx.doi.org/10.1099/00221287-142-9-2333

[43] Venosa, A.D. and Zhu, X. (2003) Biodegradation of Crude Oil Contaminating Marine Shorelines and Freshwater Wetlands. Spill Science and Technology Bulletin, 8, 163-178. http://dx.doi.org/10.1016/S1353-2561(03)00019-7

[44] Pelletier, E., Delille, D. and Delille, B. (2004) Crude Oil Bioremediation in Sub-Antarctic Intertidal Sediments: Chemistry and Toxicity of Oiled Residues. Marine Environmental Research, 57, 311-327. http://dx.doi.org/10.1016/j.marenvres.2003.07.001 
[45] Delille, D., Coulon, F. and Pelletier, E. (2004) Effects of Temperature Warming during a Bioremediation Study of Natural and Nutrient-Amended Hydrocarbon-Contaminated Sub-Antarctic Soils. Cold Regions Science and Technology, 40, 61-70. http://dx.doi.org/10.1016/j.coldregions.2004.05.005

[46] Kostka, J.E., Prakash, O., Overholt, W.A., Green, S.J., Freyer, G., Canion, A., Norton, J.D.N., Hazen, T.C. and Huettel, M. (2011) Hydrocarbon-Degrading Bacteria and the Bacterial Community Response in Gulf of Mexico Beach Sands Impacted by the Deepwater Horizon Oil Spill. Applied and Environmental Microbiology, 77, 7962-7974. http://dx.doi.org/10.1128/AEM.05402-11

[47] Olfa, B.S., Marisol, G., Monia, E.B., Robert, D. and Patricia, A. (2010) Diversity of Bacteria Able to Degrade Polyciclic Aromatic Hydrocarbons and Resistant to Metals and Antibiotics Isolated from Sediments of Bizerte Lagoon, Tunisia. Industrial, Health, and Environmental Microbiology Review, 4, 32-48.

[48] Doetsch, R.N. (1981) Determinative Methods of Light Microscopy. In: Gerdhardt, P., Murray, R.G.E., Costilow, R.N., Nester, E.W., Wood, W.A., Krieg, N.R. and Phillips, G.B., Eds., Manual of Methods for General Bacteriology, American Society for Microbiology, Washington, DC, 21-33.

[49] Fusey, P. and Oudot, J. (1976) Comparison of Two Methods for the Evaluation of in Vitro Biodegradation of Hydrocarbons. Material Und Organismen (Berlin), 11, 241-251.

[50] Kovacs, N. (1956) Identification of Pseudomonas pyocyanea by the Oxidase Reaction. Nature, 178, 703.

[51] Smibert, R.M. and Krieg, N.R. (1981) General Characterization. In: Gerdhardt, P., Murray, R.G.E., Costilow, R.N., Nester, E.W., Wood, W.A., Krieg, N.R. and Phillips, G.B., Eds., Manual of Methods for General Bacteriology, American Society for Microbiology, Washington, DC, 409-443.

[52] Atlas, R.M. and Bartha, R. (1972) Biodegradation and Mineralization of Petroleum in Seawater at Low Temperature. Canadian Journal of Microbiology, 18, 1851-1855. http://dx.doi.org/10.1139/m72-289

[53] Atlas, R.M. (1981) Microbial Degradation of Petroleum Hydrocarbons: An Environmental Perspective. Microbiological Reviews, 45, 180-209.

[54] Soltani, M. (2004) Lipids Distribution and Metabolic Pathways in Four Gram-Negative Hydrocarbonoclastes. Variation in Relation to Carbon Source. Doctorate Thesis, University of Paris VI, Paris, 288 p.

[55] Atlas, R.M. (1988) Microbiology-Fundamentals and Applications. 2nd Edition, Macmillan Publishing Co., New York, 352-353.

[56] Verstraete, W.R., Vanloocke, R., Deborger, R. and Verlinde, A. (1976) Modelling of the Breakdown and the Mobilization of Hydrocarbons in Unsaturated Soil Layers. In: Sharpley, J.M. and Kaplan, A.M., Ed., Proceedings of the 3rd International Biodegradation Symposium, Applied Science Publishers Ltd., London, 99-112.

[57] Patrick Jr., W.H. and Delaune, R.D. (1977) Chemical and Biological Redox Systems Affecting Nutrient Availability in Coastal Wetlands. Geoscience and Man, 18, 131-137.

[58] Shiaris, M.P. (1989) Seasonal Biotransformation of Naphthalene, Phenanthrene, and Benzo[a]Pyrene in Surficial Estuarine Sediments. Applied and Environmental Microbiology, 55, 1391-1399.

[59] Kerr, R.P. and Capone, D.G. (1988) The Effect of Salinity on the Microbial Mineralization of Two Polycyclic Aromatic Hydrocarbons in Estuarine Sediments. Marine Environmental Research, 26, 181-198. http://dx.doi.org/10.1016/0141-1136(88)90026-8

[60] Ward, D.M. and Brock, T.D. (1978) Hydrocarbon Biodegradation in Hypersaline Environments. Applied and Environmental Microbiology, 35, 353-359.

[61] Csonka, L.N. and Epstein, W. (1996) Osmoregulation. In: Neidhardt, F.C.R., Curtiss Iii, J.L., Ingraham, E.C.C., Lin, K. B. Low, Magasanik, et al., Eds., Escherichia coli and Salmonella: Cellular and Molecular Biology, 2nd Edition, ASM Press, Washington, DC, 1210-1223.

[62] Boethling, R.S. and Alexander, M. (1979) Effect of Concentration of Organic Chemicals on Their Biodegradation by Natural Microbial Communities. Applied and Environmental Microbiology, 37, 1211-1216.

[63] Pfaender, F.K. and Bartholome, G.W. (1982) Measurement of Aquatic Biodegradation Rates by Determining Heterotrophic Uptake of Radiolabeled Pollutants. Applied and Environmental Microbiology, 44, 159-164.

[64] Button, D.K. and Robertson, B.R. (1986) Dissolved Hydrocarbon Metabolism: The Concentration-Dependent Kinetics of Toluene Oxidation in Some North American Estuaries. Limnology and Oceanography, 3, 101-111. http://dx.doi.org/10.4319/lo.1986.31.1.0101

[65] Robertson, B.R. and Button, D.K. (1987) Toluene Induction and Uptake Kinetics and Their Inclusion in the Specific-Affinity Relationship for Describing Rates of Hydrocarbon Metabolism. Applied and Environmental Microbiology, 53, 2193-2205.

[66] Wodzinski, R.S. and Bertolini, D. (1972) Physical State in Which Naphthalene and Bibenzyl Are Utilized by Bacteria. Applied Microbiology, 23, 1077-1081. 
[67] Wodzinski, R.S. and Coyle, J.E. (1974) Physical State of Phenanthrene for Utilization by Bacteria. Applied Microbiology, 27, 1081-1084.

[68] Thomas, J.M., Yordy, J.R., Amador, J.A. and Alexander, M. (1986) Rates of Dissolution and Biodegradation of Water-Insoluble Organic Compounds. Applied and Environmental Microbiology, 52, 290-296.

[69] Yoshida, F. and Yamane, T. (1971) Hydrocarbon Uptake by Microorganisms-A Supplementary Study. Biotechnology and Bioengineering, 13, 691-695. http://dx.doi.org/10.1002/bit.260130509

[70] Bell, G.H. (1973) Solubilities of Normal, Aliphatic Acids, Alcohols and Alkanes in Water. Chemistry and Physics of Lipids, 10, 1-10. http://dx.doi.org/10.1016/0009-3084(73)90036-4

[71] Wang, D.I.C. and Ochoa, A. (1972) Measurements on the Interfacial Areas of Hydrocarbon in Yeast Fermentations and Relationships of Specific Growth Rates. Biotechnology and Bioengineering, 14, 345-360. http://dx.doi.org/10.1002/bit.260140307

[72] Nakahara, T., Erickson, L.E. and Gutierrez, J.R. (1977) Characteristics of Hydrocarbon Uptake in Cultures with Two Liquid Phases. Biotechnology and Bioengineering, 19, 9-25. http://dx.doi.org/10.1002/bit.260190103

[73] Fogel, S., Lancione, R., Sewall, A. and Boethling, R.S. (1985) Application of Biodegradability Screening Tests to Insoluble Chemicals: Hexadecane. Chemosphere, 14, 375-382. http://dx.doi.org/10.1016/0045-6535(85)90062-1

[74] Ratledge, C. (1978) Degradation of Aliphatic Hydrocarbons. In: Watkinson, R.J., Ed., Development in Biodegradation of Hydrocarbons, Vol. 1, Applied Sciences Publishers, London, 1-46.

[75] Wrenn, B.A. and Venosa, A.D. (1996) Selective Enumeration of Aromatic and Aliphatic Hydrocarbon-Degrading Bacteria by a Most-Probable Number Procedure. Canadian Journal of Microbiology, 42, 252-258. http://dx.doi.org/10.1139/m96-037

[76] Franzetti, L. and Scarpellini, M. (2007) Characterisation of Pseudomonas spp. Isolated from Foods. Annals of Microbiology, 57, 39-47. http://dx.doi.org/10.1007/BF03175048

[77] Constantiniu, S., Romaniuc, A., Iancu, L.S., Raluca, F.R. and Taraşi, I. (2004) Cultural and Biochemical Characteristics of Acinetobacter spp. Strains Isolated from Hospital Units. The Journal of Preventive Medicine, 12, 35-42. 
Scientific Research Publishing (SCIRP) is one of the largest Open Access journal publishers. It is currently publishing more than 200 open access, online, peer-reviewed journals covering a wide range of academic disciplines. SCIRP serves the worldwide academic communities and contributes to the progress and application of science with its publication.

Other selected journals from SCIRP are listed as below. Submit your manuscript to us via either submit@scirp.org or Online Submission Portal.
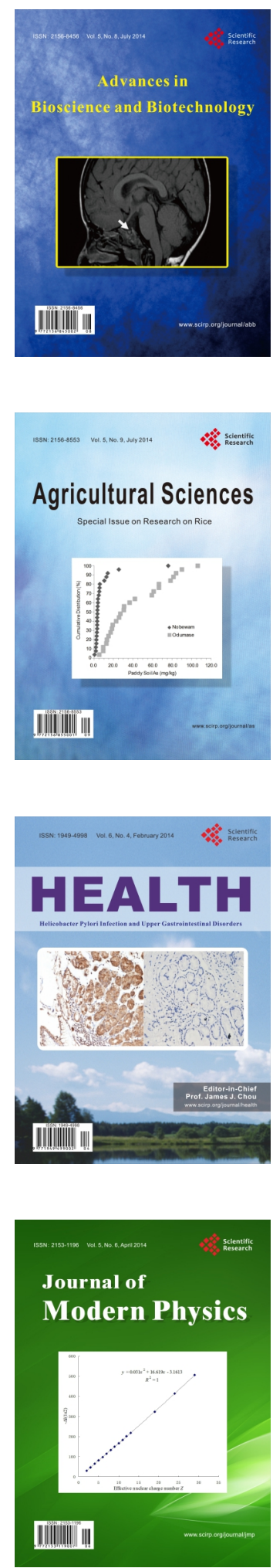
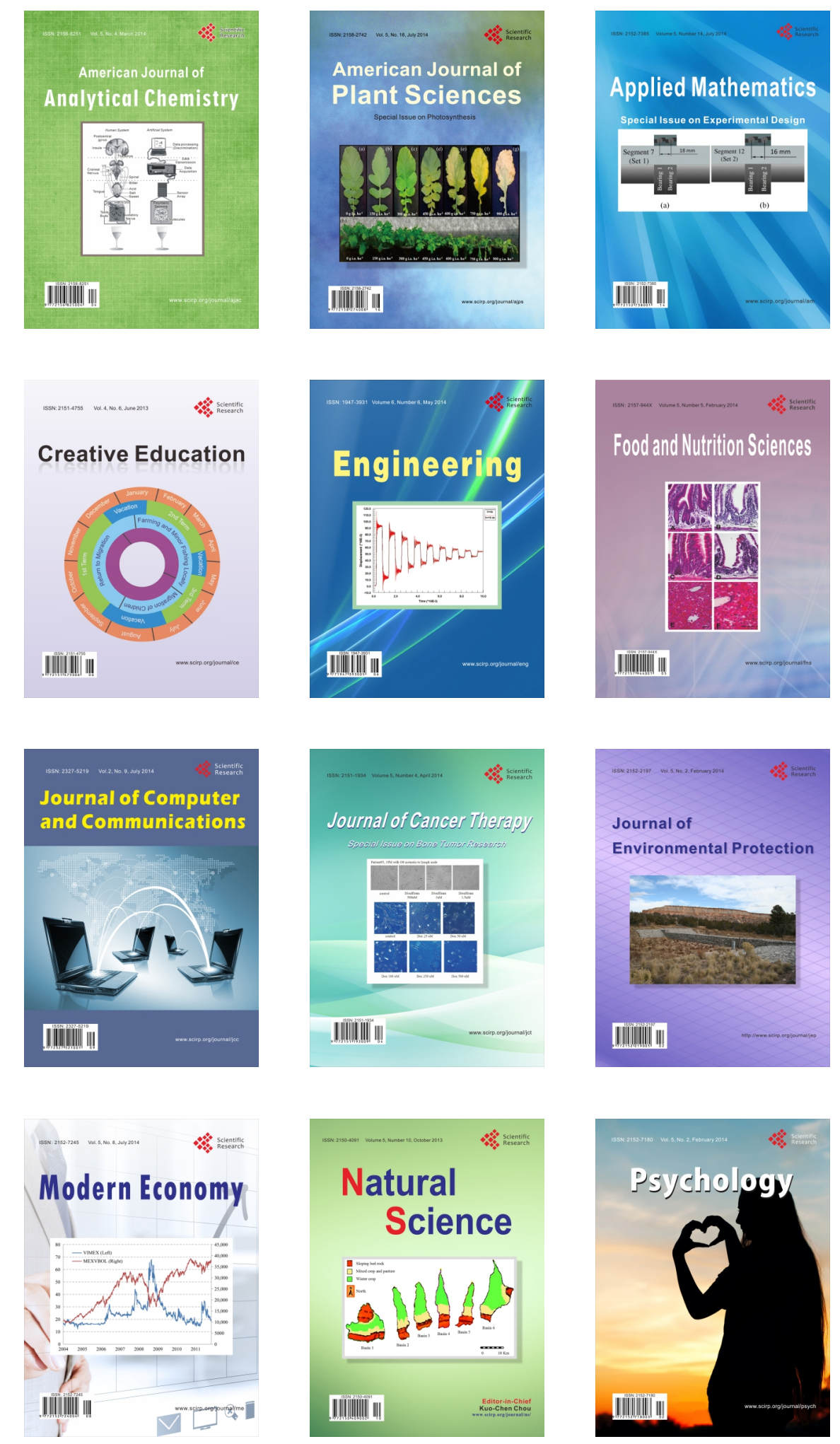